\title{
THE REMOVAL OF THE TEXTILE BASIC DYE FROM THE WATER SOLUTION BY USING NATURAL ZEOLITE
}

\author{
Goran Amin ${ }^{1 *}$, Dragan Đorđević ${ }^{1}$, Sandra Konstantinović ${ }^{1}$, Igor Jordanov ${ }^{2}$
}

(ORIGINAL SCIENTIFIC PAPER) UDC 628.358:677.027:549.67

${ }^{1}$ Faculty of Technology, Leskovac, Serbia

${ }^{2}$ Faculty of Technology and Metallurgy, Skopje, Macedonia

The use of natural zeolite for elimination of the textile basic dye from the water solution was researched in this paper. The practical simulation of purification of waste water from the textile industry was done. Zeolite was characterized by physical and chemical analysis. $\mathrm{SiO}_{2}$ dominates the chemical structure of the adsorbent, followed by: $\mathrm{Al}_{2} \mathrm{O}_{3}, \mathrm{CaO}, \mathrm{Fe}_{2} \mathrm{O}_{3}, \mathrm{~K}_{2} \mathrm{O}$. The used natural adsorbent - zeolite is a relatively fine bulk material with heterogenic porous particles, generally smaller than $45 \mu \mathrm{m}$. The effect of the initial dye concentration, $\mathrm{pH}$ and mixing time was investigated. In lower concentrations, the percentage of the removed dye is higher, but generally observed, a larger amount od dye is absorbed onto zeolite at higher initial concentrations. Longer adsorption time with a higher initial concentration results in a larger amount of the dye adsorbed by the adsorbent. The results confirm that all varied input parameters influence the efficiency of the basic dye adsorption and that the used natural zeolite, as adsorbent, has fulfilled the expectations considering the dye level after adsorption (the amount of the removed dye $>82 \%$ at $\mathrm{pH} 4$ ).
Keywords: natural zeolite, textile basic dye, adsorption, textile industry

\section{Introduction}

The treatment and processing of industrial waste waters is necessary, if nothing else because of international regulations that are getting stricter when it comes to reducing different chemicals in water. Considering this, the clean environment and ecological demands on the dye presence in waste waters have become a challenge and an issue for the dye industry and textile processing. With more stringent dye standards, the society is encouraged to reduce emission of colored wastewater into natural water flows. There is evidence that textile and paper industry wastewater contains suspicious cancinogens that are life-threatening for water organisms. Therefore, it is necessary to reduce and eliminate pollutants in the wastewater before its emission $[1,2]$.

Different processes, such as nanophotocatalysis, electrochemical and membrane processes have been used for the removal of organic pollutants from the wastewater. Adsorption turned out to be an excellent procedure for the wastewater treatment because of its advantages over conventional processes; cost-effective, simple to use, usability and the ability to treat dyes [3, 4].

It should not be forgotten that the attention of many researches is focused towards finding a possibility of using more cost-effective materials that are easily procured and applied. Different dye adsorption by using e.g. orange bark or the shell of soybean flour is already lab affirmed. The studies of adsorption of methylene blue on active coal, pods of rice, peanuts shell, glass fibers etc. were recently published [6-8].

The purpose of this paper is to eliminate dye wastewater from the textile industry by using natural zeolite, as a natural and easily accessible raw material. It is about basic dye adsorption that is mostly used for dyeing synthetic fibers. This research is basically an attempt to find an alternative method for the removal of dye from the textile industry wastewater.

\section{Experimental}

Zeolite obtained on the site near Brus, Serbia, was used as an adsorbent. The most abundant mineral phase is a mineral from the zeolite group, clynoptilolyt, with the content of mineral in the tuff around $85 \%$. After abundant rinsing with distilled water, zeolite was dried, which is the final phase before the preparation for textile basic dye adsorption.

The string of experiments with colored water was done with red textile basic dye C.I. Basic Red 46, $\mathrm{C}_{18} \mathrm{H}_{21} \mathrm{BrN}_{6}$, molar mass is $401.3 \mathrm{~g} \cdot \mathrm{mol}^{-1}$. The structure of the dye is showed in Figure 1. It is mostly used for dyeing acrylic fibers, but it can also be used for textile printing. Working dye concentrations for the experiment are defined on the base of the residual amount of the same type of the dye after dyeing the textile in the plant.

\footnotetext{
* Author address: Goran Amin, Faculty of Technology, 16000 Leskovac, Bulevar oslobodjenja 124, Serbia

E-mail: amingoran85@gmail.com

The manuscript received: October, 5, 2017.

Paper accepted: November, 28, 2017.
} 


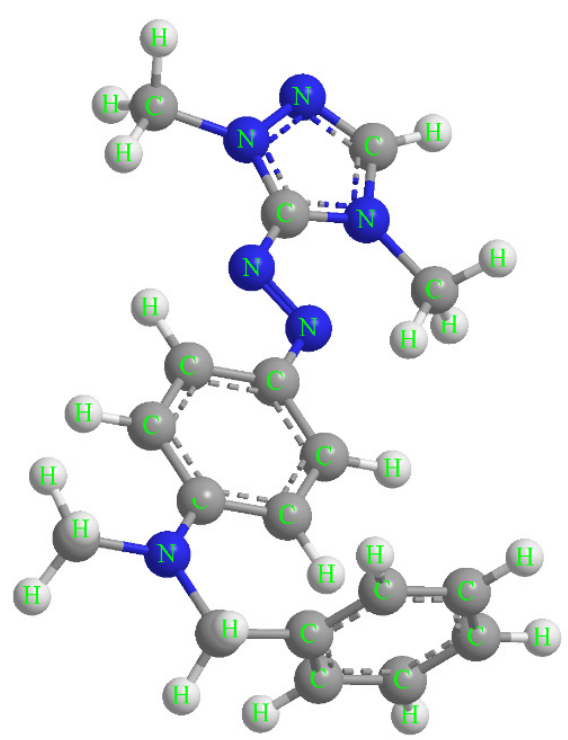

Figure 1. Structure of applied basic dye obtained by software modeling

To analyze the effect of $\mathrm{pH}$ on adsorption, $1 \mathrm{M}$ solutios $\mathrm{NaOH}$ and $\mathrm{H}_{2} \mathrm{SO}_{4}$ were used. According to the results, the most efficient adsorption of bacis cationic dye is on $\mathrm{pH} 4$; therefore, all the following experiments were conducted on this $\mathrm{pH}$.

Adsorption test itself was done in laboratory conditions, in glass reactors, placed on the shaker with 110 $\mathrm{rpm}$, at room temperature. The amount of zeolite remained $1 \mathrm{~g}$ throughout, while the constant amount of the solution $\left(100 \mathrm{~cm}^{3}\right)$ had the initial dye concentration in the range $20-100 \mathrm{mg} \cdot \mathrm{dm}^{-3}$. Contact time with continuous stirring was 2-60 min. Distilled water was used in all adsorption procedures.

Following measurement methods and calculations were used:

- Chemical composition was determined by X-ray fluorescence spectrometry (XRF) using energy dispersive spectrometer ED 2000 (Oxford Instruments, UK).

- After the deposition of a thin gold layer on the powder surface, a TESCAN MIRA 3 XMU field emission scanning electron microscope (FE-SEM), operated at $20 \mathrm{keV}$ was used to analyze the morphology of the materials.

- Dye concentration in the solution was determined by UV-VIS spectrophotometry using Cary 100 Conc UVVIS, Varian (adsorption maximum on $520 \mathrm{~nm}$ ).

- Level of the basic dye removal was calculated with the following equation [9]:

Removed dye $=\frac{C_{0}-C_{t}}{C_{0}} \cdot 100(\%)$

$C_{0}$ i $C_{t}\left(\mathrm{mg} \cdot \mathrm{dm}^{-3}\right)$ : the initial and final dye concentration in time, respectively.

- The amount of the adsorbed dye was calculated [9]:

$q_{t}=\frac{C_{0}-C_{t}}{w} \cdot V$

$q_{t}\left(\mathrm{mg} \cdot \mathrm{g}^{-1}\right)$ : mass of the adsorbed dye per zeolite mass unit (adsorbent) in adsorption time, $t ; w$ (g): adsorbent mass and $V\left(\mathrm{dm}^{3}\right)$ : volume of adsorption solution.

- Distribution of the particle size (granulometric composition) was determined by using a sieve method according to the standard SRPS EN 933-1:2013.

- Bulk density (Untapped density) according to the standard SRPS EN ISO 23145-2:2016.

- Bulk density (Tapped density) according to the standard SRPS EN ISO 23145-1:2016.

- Loss by annealing at $950^{\circ} \mathrm{C}$.

- Volume mass according to the standard SRPS B.CS.023:1997.

- Specific surface area according to the standard SRPS EN 196-6:1995.

\section{Results and discussion}

The used natural adsorbent-zeolite is relatively finegrained material with heterogeneous porous particles, with the razed shape and form, generally smaller than $45 \mu \mathrm{m}$. Micrograph in Figure 2 presents the surface morphology enlarged for 5000x. Zeolite is known as a porous material, with the indication that it is mostly macroporous with a relatively small internal surface, according to data of other researchers $[10,11]$.

It appears that the surface morphology of this adsorbent depends on the method and conditions of the production process. In fact, the adsorbent surface availability leads to fast electrostatic adsorption of cationic dye from the solution [10].

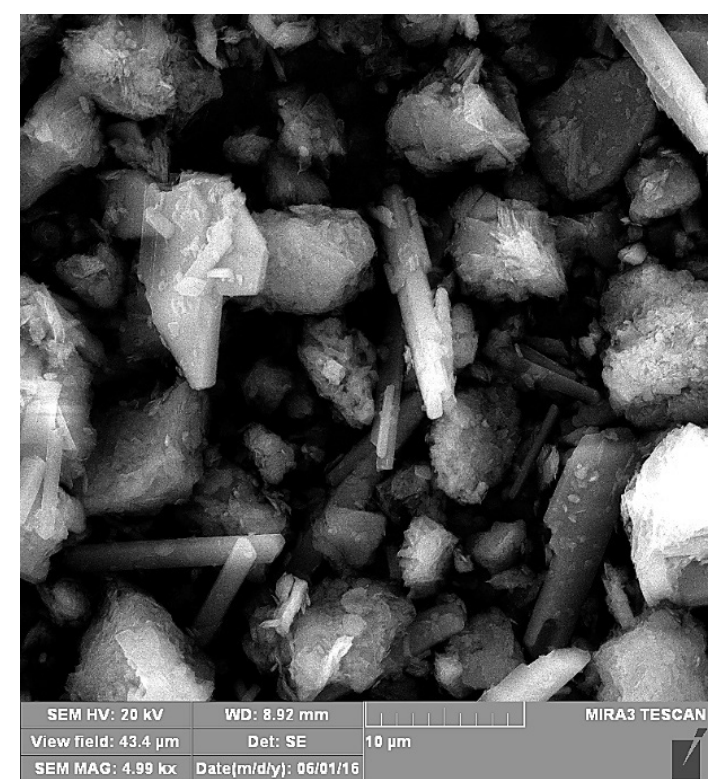

Figure 2. Particle surface micrograph of the applied adsorbent (natural zeolite)

A complete chemical analysis of the adsorbent is given in Table 1. It can be observed that $\mathrm{SiO}_{2}$ is dominant, as expected, followed by $\mathrm{Al}_{2} \mathrm{O}_{3}, \mathrm{CaO}, \mathrm{Fe}_{2} \mathrm{O}_{3}, \mathrm{~K}_{2} \mathrm{O}$ etc. 
Table 1. Chemical analysis (\%) of the native zeolite sample

\begin{tabular}{llllllllllll}
\hline $\mathrm{SiO}_{2}$ & $\mathrm{Al}_{2} \mathrm{O}_{3}$ & $\mathrm{CaO}$ & $\mathrm{Fe}_{2} \mathrm{O}_{3}$ & $\mathrm{~K}_{2} \mathrm{O}$ & $\mathbf{M g O}$ & $\mathrm{TiO}_{2}$ & $\mathrm{Na}_{2} \mathrm{O}$ & $\mathrm{MnO}$ & $\mathbf{P}_{2} \mathrm{O}_{5}$ & $\mathbf{S O}_{3}$ & $\mathrm{Cl}$ \\
\hline 58.2 & 10.6 & 8.5 & 3.5 & 2.0 & 0.9 & 0.5 & 0.1 & 0.1 & 0.1 & 0.03 & 0.008 \\
\hline
\end{tabular}

The results in Table 2 give data about certain physical properties of the adsorbent-zeolite. The charge density is greater than bulk density, as expected, water and organic matter loss by annealing is somewhat higher than $15 \%$, the volume mass is $2.25 \mathrm{~g}^{\circ} \mathrm{cm}^{-3}$, while the more important textural characteristic of zeolite, the specific surface area or the total surface area of the solid mass of the solid material has a significant number value.

Table 2. Significant physical parameters of natural zeolite

\begin{tabular}{lc}
\hline \multicolumn{1}{c}{ Parameter } & Results \\
\hline Bulk density (Untapped density), $\mathrm{g} \cdot \mathrm{cm}^{-3}$ & 0.71 \\
Bulk density (Tapped density), $\mathrm{g} \cdot \mathrm{cm}^{-3}$ & 0.83 \\
Loss by annealing at $950^{\circ} \mathrm{C}, \%$ & 15.32 \\
Volume mass, $\mathrm{g} \cdot \mathrm{cm}^{-3}$ & 2.25 \\
Specific surface area, $\mathrm{cm}^{2} \cdot \mathrm{g}^{-1}$ & 6540 \\
\hline
\end{tabular}

Granulometric composition, as a simple system for defining the grain size limit, is given it Table 3. From this Table it can be observed that the dominating zeolite particle size is $<45 \mu \mathrm{m}(26.9 \%)$ and that there is the biggest amount of grains $710-1000 \mu \mathrm{m}(2.4 \%)$.

Table 3. Granulometric composition of the adsorbent (natural zeolite)

\begin{tabular}{ccc}
\hline $\begin{array}{c}\text { Nominal sieve size } \\
(\boldsymbol{\mu m})\end{array}$ & $\begin{array}{c}\text { Mass of the granulate fraction } \\
(\mathbf{g})\end{array}$ & $\begin{array}{c}\text { Percentage share } \\
(\mathbf{\%})\end{array}$ \\
\hline 1000 & 1.6 & 3.9 \\
710 & 0.9 & 2.4 \\
250 & 9.2 & 22.9 \\
150 & 4.2 & 10.5 \\
65 & 8.6 & 21.3 \\
45 & 4.8 & 12.1 \\
Acceptable vessel & 10.8 & 26.9 \\
\hline
\end{tabular}

The $\mathrm{pH}$ effect on the adsorption of the basic dye is presented in Figure 3. The maximum dye removal is achieved on $\mathrm{pH} 4$. Between $\mathrm{pH} 5$ and $\mathrm{pH} 10$ a mild fall of the percentage of the removed dye occurs, and it is followed by the gradual growth in the amount of the removed dye, reaching maximum at $\mathrm{pH} 13$.

Generally, adsorptive characterics of the adsorbent below and above $\mathrm{pH}$ of the dye solution appear to change as a function: of surface charge of the adsorbent, a degree of ionization of adsorptive molecules and a degree of dissociation of functional groups at active adsorbent points [12].

The percentage of the removed basic dye in function of the initial concentration of the dye solution is given in Figure 4. At a lower concentration, the percentage is higher, but in general, a greater amount of the dye is adsorbed onto zeolite at higher initial concentrations. Therefore, the adsorption percentage is reduced by increasing the initial concentration of the dye in the solution actual amount of the adsorbed dye increases by increasing the initial dye concentration. During the adsorption process, dye molecules form an immobile boundary layer and then, diffusing through the boundary layer film come to the surface of the adsorbent. At the end, dye molecules penetrate into the very structure of adsorbent pores, which demands the appropriate contact time.

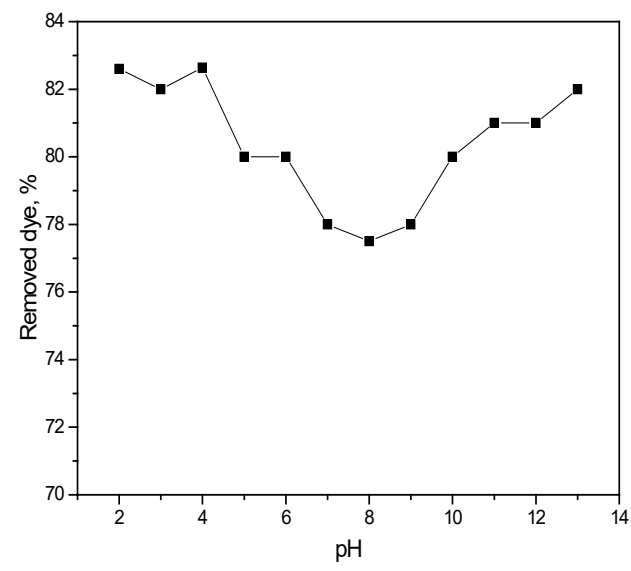

Figure 3. The effect of $\mathrm{pH}$ on the removal of the base color from the solution using natural zeolite

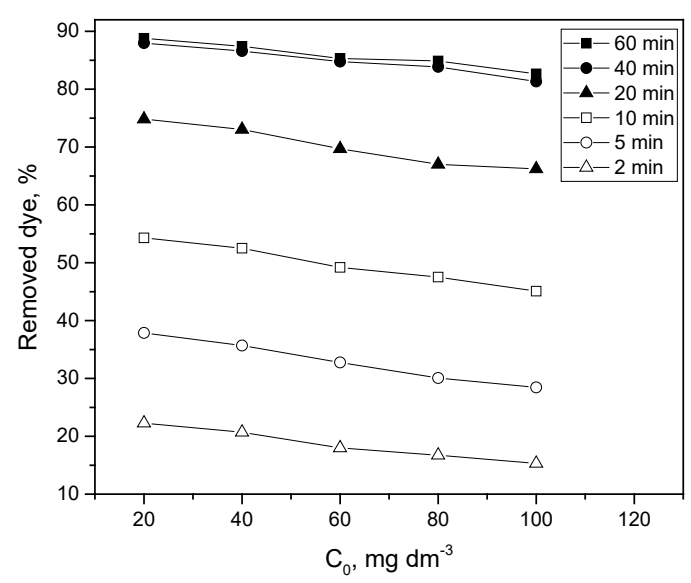

Figure 4. Amount of the removed basic dye depending on the initial concentration for the different adsorption time

The analysis of different researches has given certain correlations between the initial dye concentration and the binding capacity of the dye. In most cases, at low dye concentrations, the adsorption is more intense and the equilibrium is established faster. At constant adsorbent mass, the adsorption capacity increases by increasing the initial concentration. However, the percentage of the removed dye decreases due to aggregation or deple- 
tion of the number of active sites on the surface of the adsorbent. At low concentrations, the ratio of the initial number of dye moles and the number of available active sites on the surface of the adsorbent is very low, and in time the adsorption becomes independent of the initial concentration.

Figure 5 gives a graphic representation of the influence of the length of the contact adsorbent and adsorbate on the \% removed dye at different initial concentrations. The curves are quite consistent, which means that the adsorption mechanism is the same, regardless of the amount of adsorption actors. The large dye adsorption leap is visible at first $15-20 \mathrm{~min}$, with the subsequent slower growth of up to $60 \mathrm{~min}$. The lower initial concentration leads to higher adsorption, relatively observed, but if the absolute values are taken into account, then a greater amount of the dye is adsorbed at higher initial concentrations.

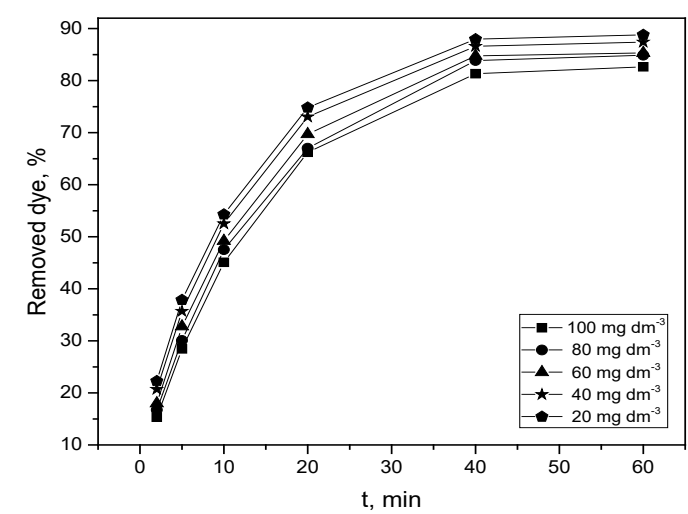

Figure 5. Removed amount of dye depending on the length of adsorption duration for different initial dye concentrations

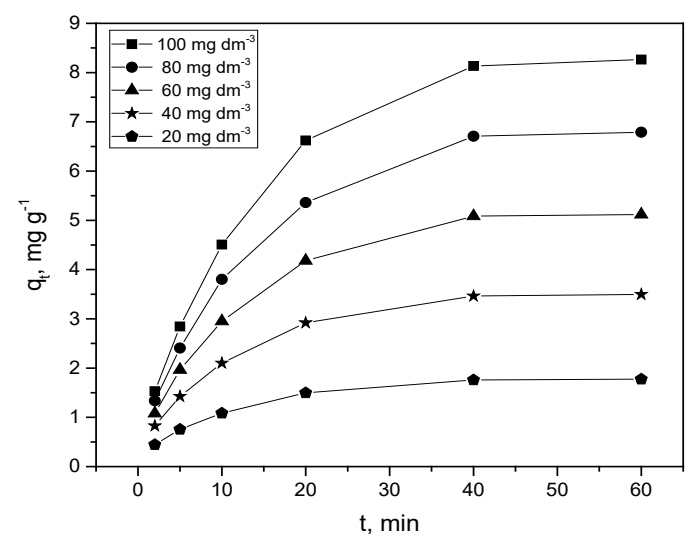

Figure 6. The amount of dye on the adsorbent, depending on the adsorption time for different initial dye concentrations

Figure 6 shows the influence of time, i.e. the length of contact on dye adsorption, i.e. demolition. The amount of the dye adsorbed per unit mass of the adsorbent is increased by increasing the initial dye concentration. At a certain initial dye concentration, the main change in the adsorbed dye occurs at the beginning of adsorption, while in the subsequent adsorption period these changes are smaller. The maximum amount of the adsorbed dye increases from $0.4-8.2 \mathrm{mg} \cdot \mathrm{g}^{-1}$ of the adsorbent when the initial dye concentration increases from 20 to $100 \mathrm{mg} \cdot \mathrm{dm}^{-3}$. The fact is that a higher concentration of the dye leads to the appearance of a larger driving force as a result of the existence of a concentration gradient. This driving force accelerates the diffusion of the dye from the solution to the adsorbent.

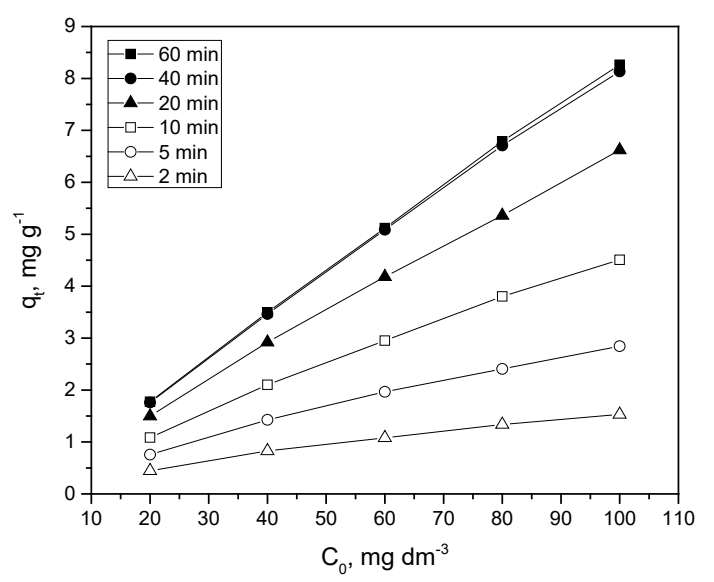

Figure 7. The amount of the dye on the adsorbent depending on the initial dye concentration for different adsorption time

Figure 7 shows a diagram of dependency of the amount of the dye adsorbed on zeolite in regard of the initial basic dye concentration. The curves on the diagram are practically functional straight lines which indicate the linear interaction qt and $\mathrm{C} o$. As expected, a longer adsorption time produces a proportionately higher amount of the dye adsorbed on the adsorbent. Also, at higher initial concentrations, the size of the $q t$ parameter increases.

\section{Conclusion}

The removal of the textile basic dye with native zeolite was analyzed under different conditions. The used natural adsorbent-zeolite is a relatively fine bulk material with heterogeneous porous particles, generally less than 45 $\mu \mathrm{m}$ in size. The chemical analysis has shown that silica oxide is dominant, as expected, followed by oxides of aluminum, calcium, iron, potassium, etc. Adsorption depends on the contact time, the initial color concentration and $\mathrm{pH}$ of the solution. Adsorption on zeolite decreases with increasing the initial dye concentration in the solution, although the actual amount of the adsorbed dye actually increases with increasing the initial dye concentration. The amount of the adsorbed dye per unit mass of zeolite is increased by increasing the contact time and the initial dye concentration. The maximum dye removal $(>82 \%)$ was achieved at $\mathrm{pH} 4$. Based on the obtained results, it 
can be said that zeolite is a very effective adsorbent for the removal of the basic dye from aqueous solutions with a justified tendency of application in industrial conditions. As a raw material, zeolite can mostly be found in Serbia at several locations, so it is expected that the treatment process by using natural zeolite is economical. The price and characteristics of adsorption favor natural zeolite as an effective adsorbent for future dye removal, for example from the wastewater of the textile industry.

\section{References}

[1] E. Ahmetović, N. Ibrić, Z. Kravanja, Održivo upravljanje vodom, otpadnom vodom i energijom u procesnoj industriji X Savjetovanje hemičara, tehnologa i ekologa Republike Srpske, Banja Luka, 15-16.11.2013., Zbornik radova, p. 150.

[2] Đ. Parac-Osterman, A. Šutlović, I. Soljačić, Voda u oplemenivanju tekstila - sirovina i otpad, Tekstil 52 (2003) 55-62.

[3] M. Lotito, M. De Sanctis, C. Di laconi, G. Bergna, Textile wastewater treatment: aerobic granular sludge vs activated sludge systems, Water Research, 54 (2014) 337-346.

[4] H. Dhaouadi, F. M. Henni, Vat dye sorption onto crude dehydrated sewage sludge, Journal of Hazardous Materials, 164 (2009) 448-458.

[5] K. Rida, S. Bouraoui, S. Hadnine, Adsorption of methylene blue from aqueous solution by kaolin and zeolite, Applied Clay Science, 83-84 (2013) 99-105.
[6] E. Alver, A. U. Metin, Anionic dye removal from aqueous solutions using modified zeolite: Adsorption kinetics and isotherm studies, Chemical Engineering Journal, 200202 (2012) 59-67.

[7] B. Armag, O. Ozdemir, M. Turan, M. Celik, The removal of reactive azo dyes. by natural and modified zeolites, Journal of Chemical Technology and Biotechnology, 78 (2003) 725-732.

[8] M. Akgul, A. Karabakan, Promoted dye adsorption performance over desilicated natural zeolite, Microporous Mesoporous Materials, 145 (2011) 157-164.

[9] Z. Sun, C. Li, D. Wu, Removal of methylene blue from aqueous solution by adsorption onto zeolite synthesized from coal fly ash and its thermal regeneration, Journal of Chemical Technology and Biotechnology, 85 (2010) 845850.

[10] K. Rida, S. Bouraoui, S. Hadnine, Adsorption of methylene blue from aqueous solution by kaolin and zeolite, Applied Clay Science, 83-84 (2013) 99-105.

[11] P. Chutia, S. Kato, T. Kojima, S. Satokawa, Adsorption of As $(V)$ on surfactant modified natural zeolites. Journal of Hazardous Materials, 162 (2009) 204-211.

[12] B. K. Naudi, A. Goswami, M. K. Purkait, Removal of cationic dyes from aqueous solutions by kaolin: kinetic and equilibrium studies, Applied Clay Science, 42 (2009) 583-590.

\section{Izvod}

\section{UKLANJANJE TEKSTILNE BAZNE BOJE IZ VODENOG RASTVORA UZ POMOĆ PRIRODNOG ZEOLITA}

Goran Amin ${ }^{1}$, Dragan Đorđević ${ }^{1}$, Sandra Konstantinović ${ }^{1}$, Igor Jordanov²

\footnotetext{
${ }^{1}$ Tehnološki fakultet, Leskovac, Srbija

${ }^{2}$ Tehnološko-metalurški fakultet, Skoplje, Makedonija
}

$U$ radu je istraživana primena prirodnog zeolita za eliminaciju tekstilne bazne boje iz vodenog rastvora. Praktično je rađena simulacija prečišćavanja otpadne vode iz tekstilne industrije. Zeolit je okarakterisan fizičkom i hemijskom analizom. U hemijskom sastavu adsorbenta dominira $\mathrm{SiO}_{2}$, zatim slede $\mathrm{Al}_{2} \mathrm{O}_{3}, \mathrm{CaO}, \mathrm{Fe}_{2} \mathrm{O}_{3}, \mathrm{~K}_{2} \mathrm{O}$. Korišćeni prirodni adsorbent-zeolit je relativno fino rasuti materijal sa heterogenim poroznim česticama, generalno, veličine ispod $45 \mu \mathrm{m}$. Istraživan je uticaj početne koncentracije boje, pH i vremena mešanja na adsorpciju. Kod nižih koncentracija, javlja se veći procenat uklonjene boje, ali posmatrano generalno, veća količina boje je adsorbovana na zeolit kod viših početnih koncentracija. Duže vreme adsorpcije pri višim početnim koncentracijama proizvodi veću količinu boje adsorbovane na adsorbentu. Rezultati potvrđuju da svi varirani ulazni parametri utiču na efikasnost adsorpije bazne boje, kao i da je primenjeni prirodni zeolit, kao adsorbent, ispunio očekivanja s obzirom na nivo obojenosti posle adsorpcije (količina uklonjene boje $>82 \%$ pri $\mathrm{pH} 4$ ).
(ORIGINALNI NAUČNI RAD) UDK 628.358:677.027:549.67

Ključne reči: prirodni zeolit, bazna boja adsorpcija, tekstilna industrija. 